${ }^{1}$ INERA, Ouagadougou, Burkina Faso

${ }^{2}$ SERIDA-Somió, Gijón (Asturias), Spain

${ }^{3}$ CIRDES, Bobo-Dioulasso, Burkina Faso

${ }^{4}$ ISRA, Dakar Ouakam, Sénégal

${ }^{5}$ CIRAD-Campus de Baillarguet, Montpellier, France

${ }^{6}$ INRA-SAGA Toulouse, Castanet Tolosan Cedex, France

${ }^{7}$ Université de Ouagadougou. (UFR/SVT), Ouagadougou, Burkina Faso

\author{
AMADOU TRAORÉ ${ }^{1,2}$, HAMIDOU H. TAMBOURA ${ }^{1}$, ADAMA KABORE ${ }^{1}$, LUIS J. ROYO ${ }^{2}$, \\ IVÁN FERNÁNDEZ ${ }^{2}$, ISABEL ÁLVAREZ ${ }^{2}$, MAMADOU SANGARE ${ }^{3}$, DIDIER BOUCHEL ${ }^{4}$, \\ JEAN PAUL POIVEY ${ }^{5}$, DOMINIQUE FRANCOIS ${ }^{6}$, LAYA SAWADOGO ${ }^{7}$ and FÉLIX \\ GOYACHE $^{2}$
}

\title{
Multivariate analyses on morphological traits of goats in Burkina Faso
}

\begin{abstract}
A total of 10,147 female goats from Burkina Faso were scored for 7 body measures and 12 qualitative traits. Sampling included the three main environmental areas and goat breeds of Burkina Faso: the Sahel area (Sahelian goat), the Sudan-Sahel area (Mossi goat) and the Sudan area (Djallonké goat). Overall, the Sahelian goat had the highest values for the all the analysed body measures. Differences between the Sudan and the Sudan-Sahel goat were little. The Burkina Faso goat is mainly spotted $(61.92 \%)$ with horns type "Spanish Ibex" (84.05\%), frequent absence of beard $(75.33 \%)$ and wattles $(70.92 \%)$ and poorly developed udder $(73.72 \%)$. The Sahelian population included most individuals with dropping (95.60\%) and curled $(73.62 \%)$ ears, whilst most Sudan-Sahel individuals had horizontal ears $(73.14 \%)$ and most Sudan individuals had vertical ears $(97.88 \%)$. The largest Mahalanobis distance was found between the Sahelian and Sudan areas (7.50) whilst the Sudan and the Sudan-Sahel populations were poorly differentiated (1.15). Discriminant analysis showed that most Sahel and Sudan-Sahel individuals were classified into their source population $(79.29 \%$ and $82.69 \%$ ) whilst the Sudan individuals $(93.40 \%)$ were classified as Sudan-Sahel individuals. Both the canonical and the correspondence analyses showed that the Sahelian and Sudan individuals tended to cluster separately whilst the Sudan-Sahel individuals showed an intermediate distribution but clearly biased toward the Sudan individuals. The Sudan-Sahel (Mossi) population can be considered a result from the genetic contact between Sahelians and Sudan goats
\end{abstract}

Keywords: Djallonké goat, Mossi goat, Sahel goat, Africa, local breed, morphological traits, genetic resources

\section{Zusammenfassung}

Titel der Arbeit: Multivariate Analyse von morphologischen Merkmalen der Burkina-Faso-Ziege

An insgesamt 10.147 weiblichen Ziegen aus Burkina Faso wurden 7 Körpermaße und 12 qualitative Merkmale bewertet. Die Probennahme wurde in den drei Haupthabitaten an den wichtigsten Ziegenrassen von Burkina Faso durchgeführt: Sahelzone (Sahel-Ziege), Sudan-Sahelzone (Mossi-Ziege) und Sudangebiet (DjallonkéZiege). Insgesamt erreichte die Sahel-Ziege die höchsten Werte bei allen untersuchten Körpermaßen. Die Unterschiede zwischen der Sudan-Ziege und der Sudan-Sahel-Ziege waren gering. Die Burkina-Faso-Ziege ist überwiegend gefleckt (61.92\%), mit Hörnern vom Typ "Spanish Ibex" (84.05\%), häufig bartlos (75.33\%) und ohne Kehllappen (70.92\%) sowie unzureichend entwickeltem Euter (73.72\%). Die meisten der Individuen der Sahel-Population wiesen hängende (95.60\%) und gekrauste Ohren (73.62\%) auf, während die meisten der Individuen aus der Sudan-Sahel-Zone waagerechte Ohren (73.14\%) und die Mehrheit der Individuen aus dem Sudangebiet aufrecht stehende Ohren $(97.88 \%)$ hatten. Die größte Mahalanobis-Distanz wurden zwischen den Sahel- und Sudangebieten gefunden $(7,50)$, während sich die Sudan- und Sudan-Sahel-Populationen nur geringfügig voneinander unterschieden (1,15). Diskriminanzanalysen zeigten, dass die meisten der Sudan- und Sudan-Sahel-Individuen ihrer Quellpopulation zugeordnet wurden (79.29\% und 82.69\%), während die Individuen aus dem Sudangebiet (93.40\%) als Sudan-SahelIndividuen eingeordnet wurden. Sowohl die kanonischen als auch die Korrepondenzanalysen zeigten, dass die Sahel- und Sudan-Individuen dazu neigten, getrennt zu clustern, während die Sudan-Sahel-Individuen 
eine Zwischenverteilung, aber deutlich ausgerichtet auf die Sudan-Individuen, aufwiesen. Die Sudan-SahelPopulation (Mossi) kann als Ergebnis des genetischen Kontakts zwischen den Ziegen aus dem Sahel- und dem Sudangebiet angesehen werden.

Schlüsselwörter: Djallonké Ziegen, Mossi Ziegen, Sahel Ziegen, Afrika, lokale Populationen, morphologische Merkmale, genetische Ressource

Introduction

The Burkina Faso goat population is formed by a total of 10,035,687 heads. This livestock represent the $69.5 \%$ of the domestic ruminants exploited in this country (ENEC II, 2004). Goat plays a major role in maintenance of rural populations in conditions of extreme poverty in Burkina Faso and also has a major cultural importance (TAMBOURA and BERTÉ, 1994). Information on goat resources of Burkina Faso is scarce (SANFO et al., 2000; TRAORÉ et al., 2006) and limited to the gathering of qualitative and body traits in local populations. This scenario does not allow an accurate identification of genetic types and breeds at the national level to be further characterised at both the production and the genetic levels.

Even though there are not clearly defined breeds within the Burkina Faso goat some consensus exists among the rural communities countryside to roughly recognise three main goat entities that can be considered as breeds (SIMON, 1999): the Djallonké, the Mossi and the Sahelian breeds. These breeds inhabit, respectively, one of the three different environmental areas in which Burkina Faso can be divided: the Sudan area, the Sudan-Sahel area and the driest Sahel area. The sheep populations of these three environmental areas of Burkina Faso number, respectively, 2,113,040, 4,598,519 and 3,324,128 heads (ENEC II, 2004). However, information from the native Burkina Faso goat breeds is not rich (DAGRIS, 2007), regardless the breed is the operation unit for the assessment of livestock diversity all over the world (DUCHEV and GROENEVELD, 2006; DUCHEV et al., 2006; SIMON, 1999).

The first step of the characterisation of local genetic resources falls on the knowledge of the variation of morphological traits (DELGADO et al., 2001). Based on preliminary studies carried out on Mediterranean goats (LAUVERGNE et al., 1992) the morphometric criteria generally used to classify West African goats (DOSSA et al., 2007) are: height at withers (HW), thorax depth (TD) and ear length (EL). BOURZAT et al. (1993) also proposed the use of two combined indices that have shown good performance in differentiating homogeneous subpopulations within the Cameroonian and the Chadian goat populations (BOURZAT et al., 1993; ZEUH et al., 1997): the slenderness index and the auricle-thorax index. However, such type of indices have limited power and multifactorial analyses of morphological traits are more appropriate to assess variation within and between goat populations (CAPOTE et al., 1998; DOSSA et al., 2007; HERRERA et al., 1996; JORDANA et al., 1993; LANARI et al., 2003; ZAITOUN et al., 2005) and appropriately discriminate different goat types because all measured morphological variables are considered jointly.

A total of 7 body measures and 12 qualitative phenotypic traits were analysed in Burkina Faso goat. Data were obtained from an extensive sampling all over the country territory to better characterise the whole Burkina Faso goat population. Throughout the paper we shall attempt to address the following questions:

a) How morphologically heterogeneous the Burkina Faso goat population is?

b) Has the classification of Burkina Faso goat into different breeds scientific support? 


\section{Materials and methods}

\section{Environmental areas and goat populations}

The Burkina Faso territory can be divided in three main environmental areas according to climate conditions and types of vegetation (OUADBA, 1997; Figure 1):

a) the Sahel area (SA)

b) the Sudan-Sahel area (SS) and

c) the Sudan area (SU).

The Sahel domain is an arid area covering the northern part of Burkina Faso (from latitude $13^{\circ} 5^{\prime} \mathrm{N}$ to $15^{\circ} 3^{\prime} \mathrm{N}$, approximately) with annual rainfall $<600 \mathrm{~mm}$, temperatures varying from $15^{\circ} \mathrm{C}$ to $47^{\circ} \mathrm{C}$, and grassy, bushy, shrubby and thicket steppe vegetation, usually quite sparse, with ligneous species that may locally form penetrable bushes. The Sudan-Sahel domain is a transitional zone with regards to rainfall and temperature, covering the central part of the country (roughly from latitude $11^{\circ} 3^{\prime} \mathrm{N}$ to $13^{\circ} 5^{\prime} \mathrm{N}$ ), with a short rainy season from June to September and very variable rainfall with average of $750 \mathrm{~mm}$. per year, temperatures varying between $20^{\circ} \mathrm{C}$ and $42^{\circ} \mathrm{C}$, and vegetation varying from North to South with better hydric conditions, from the Sahel to the Sudan savannah to tend eventually toward a clear forest in the Southwestern extreme of the domain. The Sudan domain covers Southern Burkina Faso (latitude from $9^{\circ} 3^{\prime} \mathrm{N}$ to $11^{\circ} 3^{\prime} \mathrm{N}$ ), shares with the Sudan-Sahel area a similar rainy season with annual rainfall $>900 \mathrm{~mm}$ and a predominance of woodlands and both Sudanese- and Guinean-type savannahs; temperatures are relatively low varying from $17^{\circ} \mathrm{C}$ to $35^{\circ} \mathrm{C}$.

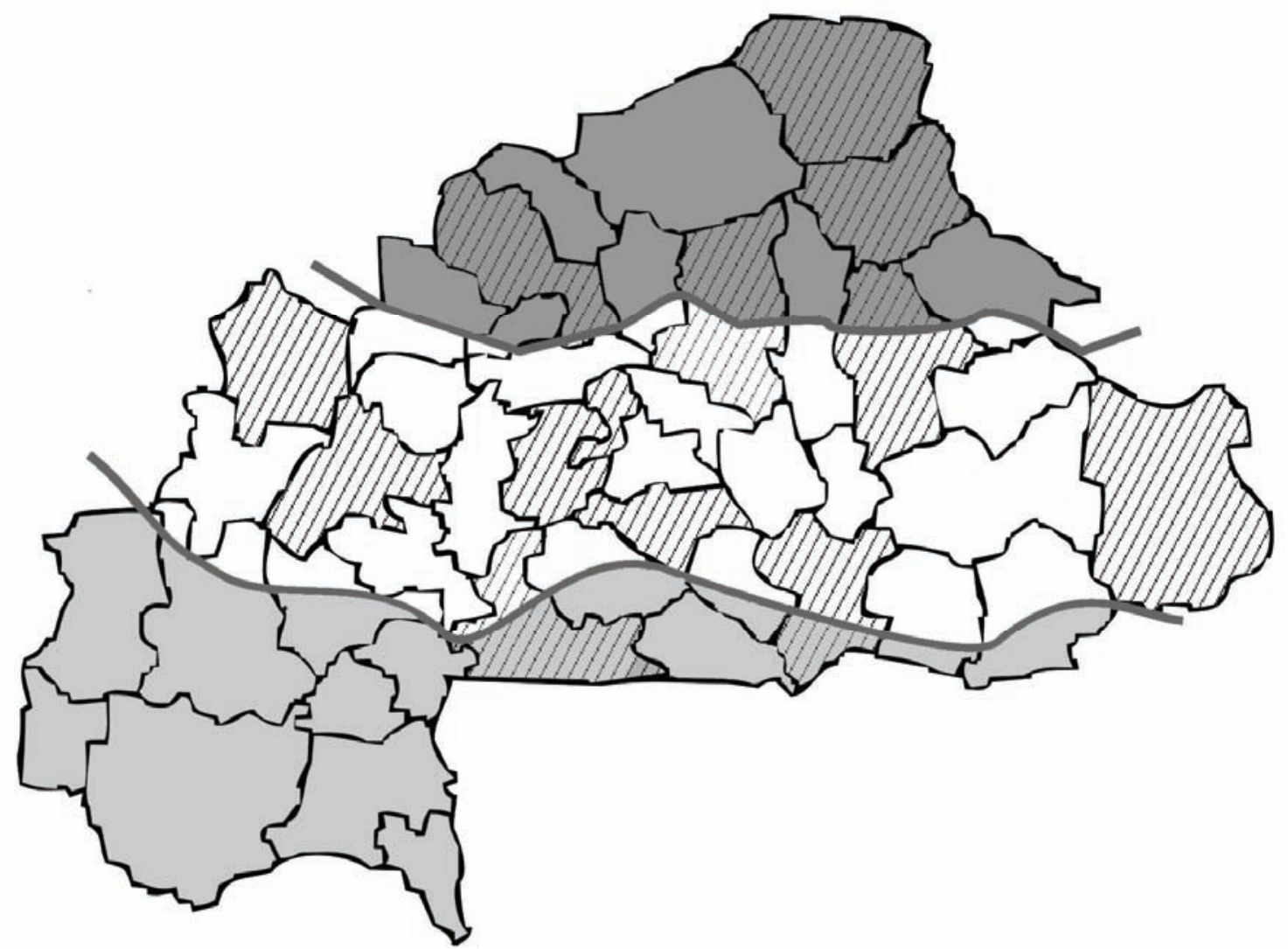

Fig. 1: Map, adapted from Ouadba (1997), illustrating the division in provinces of Burkina Faso and the limits of the main environmental area of identified in the country. The dashed provinces are those in which the the sampling was carried out.

(Angepasste Karte von Ouadba [1997], die die Unterteilung von Burkina Faso in Provinzen und die Grenzen der Haupthabitate im Land darstellt. In den gestrichelt dargestellten Porvinzen wurde die Probennahme durchgeführt.) 
The three environmental areas described above are assumed to gather three different goat breeds:

a) the Djallonké dwarf breed, located in the Sudan area, is a short-eared and smallhorned goat belonging to the West African Dwarf goat population, which is spread throughout the African Atlantic coastline from Bissau Guinea to Congo,

b) the Sahelian breed, which is the Burkina Faso representative of the longlegged goat group spread throughout the Sahel region of West Africa, from western Sudan in the east to Mauritania and Senegal in the west; and

c) the Mossi breed, located in the Sudan-Sahel area of Burkina Faso, which is considered a transition breed probably nearer to the Djallonké breed (TAMBOURÁ et al., 1998; TRAORÉ et al., 2006).

Throughout the paper, goat populations sampled in each environmental area (Sahel, Sudan-Sahel and Sudan areas) will be considered as belonging to a different breed (Sahelian, Mossi and Djallonké breeds, respectively). Further descriptions of the main goat groups listed above can be found in MASON (1991) and WILSON (1991).

\section{Data collection}

From May 2006 to April 2007, sampling was carried out in a total of 168 villages (VIL) belonging to 13 provinces of Burkina Faso, covering the three identified environmental areas in the country (Table 1, Figure 1). Within VIL, from 2 to 5 different flocks were sampled. According to BOUCHEL (1995), a total of 10,147 female individuals from 2.5 to 5 years old were scored for 7 body measures and 12 qualitative traits. The age of the animal was estimated from its dentition. Up to 4,422 individuals were sampled in the Sahel area, 4,391 in the Sudan-Sahel area and 1,334 in the Sudan area. Geographic location for each VIL was georeferenced using a GPS Garmin 50.

Table 1

Description of sampling (Beschreibung der Probennahme)

\begin{tabular}{|c|c|c|c|c|c|}
\hline \multirow{2}{*}{ Provinces } & \multicolumn{2}{|c|}{ Sampling number } & \multicolumn{3}{|c|}{ Environmental areas } \\
\hline & Villages & Individuals & Sahel & Sudan & Sudan-Sahel \\
\hline Bazéga & 8 & 482 & & & 482 \\
\hline Boulgou & 9 & 543 & & 543 & \\
\hline Boulkiemdé & 18 & 1,083 & & & 1,083 \\
\hline Gnagna & 19 & 1,145 & 660 & & 485 \\
\hline Kossi & 7 & 420 & & & 420 \\
\hline Mouhoun & 9 & 543 & & & 543 \\
\hline Oudalan & 11 & 668 & 668 & & \\
\hline Sanmatenga & 15 & 905 & 482 & & 423 \\
\hline Seno & 29 & 1,756 & 1,756 & & \\
\hline Sissili & 13 & 791 & & 791 & \\
\hline Tapoa & 11 & 663 & & & 663 \\
\hline Yatenga & 14 & 856 & 856 & & \\
\hline Kourwéogo & 5 & 292 & & & 292 \\
\hline Totals & 168 & 10,147 & 4,422 & 1334 & 4,391 \\
\hline
\end{tabular}

Body measurements were carried out by 4 different technicians using Lydthin stick and tape measure; animals were put on a flat floor and managed by the respective owners. The 7 body measures obtained were: Horn Length (HL, from base to tip), Horns Separation (HS, distance between the beginnings of the horns), Tips Separation (TS, distance between the tips of the horns), Ear Length (EL), Thorax Depth (TD), Body Length (BL, distance from distance between the point of the 
shoulder, lateral tuberosity of the humerus, and the pinbone or tuber ischii), and Height at Withers (HW). From these body measures two indices were generated according to BOURZAT et al. (1993): the slenderness index (SI=[HW-TD $] / T D)$ and the auricular index $(\mathrm{AI}=\mathrm{EL} / \mathrm{TD})$. The 12 qualitative traits scored were: Colour Pattern (CP, with 5 levels), Melanin Type (MT, three levels), incident of Roan (R, presence/absence), Belt (B, with 4 levels), incident of Frosting (F, presence/absence), incidence of beard (B, presence/absence), incidence of Wattles (W, presence/absence), incidence of Long Hairs (LH, presence/absence), Horns Type (HT, with 5 levels), Ear Position (EP, with 4 levels), Ear Curling (EC, presence/absence), and Udder Development (UD, with 3 levels).

\section{Statistical analyses}

Statistical analyses were carried out using the SAS/STAT package (1999). Basic statistics for the body measures and qualitative traits were obtained using the PROC UNIVARIATE and PROC FREQ. The influence of the environmental area on the 7 body traits measured was assessed using the PROC MIXED, fitting a model including as effects the Area (with 3 levels: Sahel, Sudan-Sahel and Sudan) and VIL, as a random variable, nested within area to account for the non-independency of sampling in each VIL. Least square means and their corresponding standard errors were obtained for each body trait and area level. Additionally, DUNCAN's multiplerange test was performed on all area means affecting body measure traits using PROC GLM. The CANDISC procedure was used to perform canonical analyses to derive canonical functions, linear combinations of the quantitative variables that summarize variation between Areas and compute the between-Areas Mahalanobis distance matrix. The ability of the computed canonical functions to assign each individual goat to its environmental area was calculated as the percent correct assignment of each vegetation zone using the DISCRIM procedure. The association between the qualitative traits was assessed via a correspondence analysis using the PROC CORRESP of SAS. Both the canonical values and the eigenvectors computed for each individual via, respectively, canonical and correspondence analyses were regressed on geographical latitude using the PROC REG of SAS/STAT. When necessary for descriptive purposes, canonical variables and correspondence analysis dimensions were plotted using Microsoft Excel ${ }^{\mathrm{TM}}$.

\section{Results}

\section{Continuous traits}

Least squared means for the body measures analysed by environmental area are given in Table 2. Overall, the Sahelian goat had the highest values for the all the analysed traits and indices: $16.40 \mathrm{~cm}$ for EL, $25.22 \mathrm{~cm}$ for TD, $56.66 \mathrm{~cm}$ for BL and 61.10 for HW. Differences between the Sudan and the Sudan-Sahel goat were little even though most traits showed higher average values in the Sudan-Sahel (Mossi) goat except for TD and BL. In any case, both the slenderness and the auricular index had higher values in the Sudan-Sahel population than in the Sudan goat (Djallonké): $1.20-1.07$ and $0.50-0.43$, respectively. 
Table 2

Raw means, standard error (SE) and coefficient of variation (CV) for each of the 7 body measures and 2 indices analysed. Least squared means and their standard errors (LSM $\pm \mathrm{SE}$ ) are also given by environmental areas.

(Ausgangsmittel, Standardfehler [SE] und Variationskoeffizient [CV] für jedes der untersuchten 7 Körpermaße und 2 Indizes. Least squared means und ihre Standardfehler (LSM $\pm \mathrm{SE}$ ) sind auch durch die Habitate gegeben.)

\begin{tabular}{|c|c|c|c|c|c|}
\hline \multirow[b]{2}{*}{ Trait $^{1}$} & \multicolumn{3}{|c|}{ Environmental area } & \multicolumn{2}{|l|}{ Totals } \\
\hline & $\begin{array}{c}\text { Sahel } \\
\mathrm{LSM} \pm \mathrm{SE}\end{array}$ & $\begin{array}{c}\text { Sudan } \\
\mathrm{LSM} \pm \mathrm{SE}\end{array}$ & $\begin{array}{c}\text { Sudan-Sahel } \\
\mathrm{LSM} \pm \mathrm{SE}\end{array}$ & Raw mean $\pm \mathrm{SE}$ & $\mathrm{CV}$ \\
\hline Horn Length & $14.18^{\mathrm{a}} \pm 0.05$ & $7.46^{b} \pm 0.09$ & $9.02^{c} \pm 0.05$ & $11.14 \pm 0.5$ & 44.86 \\
\hline Horns Separation & $6.75^{\mathrm{a}} \pm 0.02$ & $5.47^{b} \pm 0.03$ & $6.28^{\mathrm{c}} \pm 0.02$ & $6.38 \pm 0.01$ & 22.04 \\
\hline Tips Separation & $15.29^{\mathrm{a}} \pm 0.06$ & $7.99^{b} \pm 0.11$ & $10.35^{\mathrm{c}} \pm 0.06$ & $12.28 \pm 0.06$ & 41.95 \\
\hline Ear Length & $16.40^{\mathrm{a}} \pm 0.03$ & $10.13^{b} \pm 0.06$ & $11.51^{\mathrm{c}} \pm 0.03$ & $13.48 \pm 0.04$ & 29.11 \\
\hline Thorax Depth & $25.22^{\mathrm{a}} \pm 0.03$ & $23.67^{b} \pm 0.05$ & $23.07^{\mathrm{c}} \pm 0.03$ & $24.06 \pm 0.02$ & 10.44 \\
\hline Body Length & $56.66^{\mathrm{a}} \pm 0.67$ & $51.86^{\mathrm{b}} \pm 1.22$ & $51.18^{b} \pm 0.67$ & $53.68 \pm 0.45$ & 84.07 \\
\hline Height at Withers & $61.10^{\mathrm{a}} \pm 0.06$ & $48.80^{\mathrm{b}} \pm 0.11$ & $50.36^{\mathrm{c}} \pm 0.62$ & $54.86 \pm 0.09$ & 15.78 \\
\hline Slenderness index & $1.43^{\mathrm{a}} \pm 0.002$ & $1.07^{\mathrm{b}} \pm 0.004$ & $1.2^{\mathrm{c}} \pm 0.002$ & $1.28 \pm 0.002$ & 19.41 \\
\hline Auricular index & $0.65^{\mathrm{a}} \pm 0.001$ & $0.43^{b} \pm 0.002$ & $0.50^{\mathrm{c}} \pm 0.001$ & $0.56 \pm 0.001$ & 25.72 \\
\hline
\end{tabular}

${ }^{1}$ In cm except for the two analysed indices; different letters as superscripts means significant differences for $\mathrm{p}<0.05$

\section{Qualitative traits}

Incidence (in percentage) of each level of the 12 qualitative traits recorded for the total population and for each environmental area is given in Table 3. The native Burkina Faso goat is mainly spotted $(61.92 \%)$ with horns type "Spanish Ibex" $(84.05 \%)$, frequent absence of beard $(75.33 \%)$ and wattles $(70.92 \%)$, absence of long hair $(98.74 \%)$ and poorly developed udder $(73.72 \%)$. Some characteristics, such as the presence of roan or frosting, are shared by roughly a half of the total population. The Sahelian population included most individuals with dropping $(95.60 \%)$ and curled $(73.62 \%)$ ears, whilst most Sudan-Sahel (Mossi) individuals had horizontal ears (73.14\%) and most Sudan individuals had vertical ears $(97.88 \%)$. Sahelians had non-"Spanish Ibex" horns in significant frequency.

\section{Multivariate analyses}

The canonical analysis allowed identifying two canonical variables (CAN1 and CAN2) statistically significant for $\mathrm{p}<0.0001$. The CAN 1 and CAN 2 accounted for $94 \%$ and $5.5 \%$ of the total variation, respectively. Figure 2 shows a bidimensional plot illustrating the between body measure relationships: on the $\mathrm{X}$-axis, $\mathrm{BL}$ is separated from the other traits characterising "body size" (HW, EL, HL and TS) whilst on the Y-axis the two traits characterising "body width" (HS and, particularly, TD) are well separated.

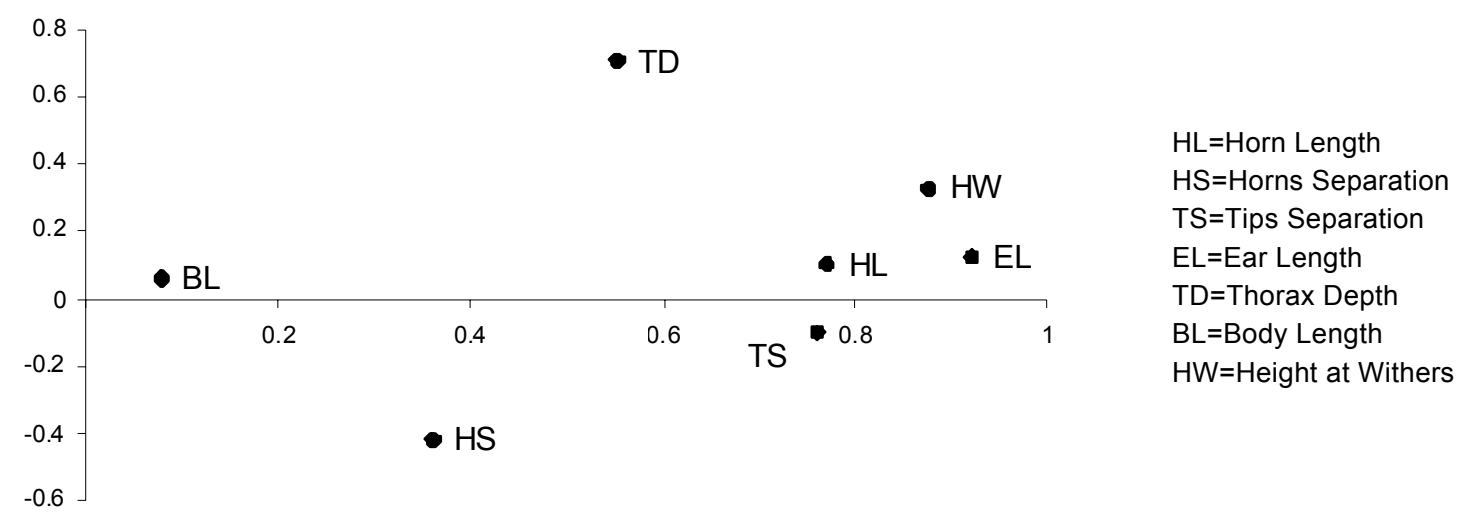

Fig. 2: Bi-dimensional plot illustrating the association between body measures in Burkina Faso goat assessed via canonical analysis (Zweidimensionales Schaubild zur Darstellung des Zusamenhangs zwischen Körpermaßen bei der Burkina-Faso-Ziege, ausgewertet durch kanonische Analyse) 
Table 3

Total frequency (and percentage in brackets) for each level of the qualitative traits scored in Burkina Faso goat. The frequency of each class level is also described within environmental area. (Gesamthäufigkeit [und Prozentanteil in Klammern] für jedes Level der an der Burkina-Faso-Ziege bewerteten qualitativen Merkmale. Die Häufigkeit für jeden Gruppenlevel ist auch im jeweiligen Habitat beschrieben.)

\begin{tabular}{|c|c|c|c|c|c|c|c|c|c|}
\hline \multirow{2}{*}{ Variables } & \multirow{2}{*}{ Class level } & \multirow{2}{*}{\multicolumn{2}{|c|}{ Total population }} & \multicolumn{6}{|c|}{ Environmental area } \\
\hline & & & & & ahel & & Idan & Suda & -Sahel \\
\hline \multirow{5}{*}{ Coat pattern } & black & 969 & $(9.55)$ & 290 & $(29.93)$ & 172 & $(17.75)$ & 507 & $(52.32)$ \\
\hline & black/ red & 271 & $(2.67)$ & 38 & $(14.02)$ & 92 & $(33.95)$ & 141 & $(52.03)$ \\
\hline & red & 1,514 & $(14.92)$ & 471 & (31.11) & 233 & $(15.39)$ & 810 & $(53.5)$ \\
\hline & spotted & 6,283 & $(61.92)$ & 3,543 & $(56.39)$ & 212 & $(3.37)$ & 2,528 & $(40.24)$ \\
\hline & wild & 111 & $(10.94)$ & 80 & $(7.21)$ & 625 & $(56.31)$ & 405 & $(36.49)$ \\
\hline \multirow{3}{*}{ Melanin type } & black & 5,454 & $(53.75)$ & 2,059 & $(37.75)$ & 1,063 & $(19.49)$ & 2,332 & $(42.76)$ \\
\hline & brown & 2,284 & $(22.51)$ & 910 & $(39.84)$ & 124 & $(5.43)$ & 1,250 & $(54.73)$ \\
\hline & others & 2,409 & $(23.74)$ & 1,453 & $(60.32)$ & 147 & $(6.1)$ & 809 & (33.58) \\
\hline \multirow{2}{*}{ Roan } & absence & 5,007 & $(49.34)$ & 2,883 & $(57.58)$ & 600 & $(11.98)$ & 1,524 & $(30.44)$ \\
\hline & presence & 5,140 & $(50.66)$ & 1,540 & (29.94) & 730 & (14.28) & 2,870 & $(55.78)$ \\
\hline \multirow{4}{*}{ Belt } & absence & 3,094 & $(30.49)$ & 1,054 & $(34.07)$ & 796 & $(25.73)$ & 1,244 & $(40.21)$ \\
\hline & limited to belly & 2,936 & $(28.93)$ & 644 & $(21.93)$ & 452 & $(15.4)$ & 1,840 & $(62.67)$ \\
\hline & presence & 275 & $(2.71)$ & 125 & $(45.45)$ & 59 & $(21.45)$ & 91 & (33.09) \\
\hline & others & 3,842 & $(37.86)$ & 2,599 & $(67.65)$ & 27 & $(0.7)$ & 1,216 & (31.65) \\
\hline \multirow{2}{*}{ Frosting } & absence & 5,184 & $(51.09)$ & 3,033 & $(58.51)$ & 408 & $(7.84)$ & 1,743 & (33.62) \\
\hline & presence & 4,963 & $(48.91)$ & 1,389 & (27.99) & 926 & $(18.66)$ & 2,648 & $(53.35)$ \\
\hline \multirow{2}{*}{ Beard } & absence & 7,644 & $(75.33)$ & 2,909 & $(38.06)$ & 1,163 & $(15.21)$ & 3,572 & $(46.73)$ \\
\hline & presence & 2,503 & (24.67) & 1,513 & $(60.45)$ & 171 & $(6.83)$ & 819 & $(32.72)$ \\
\hline \multirow{2}{*}{ Wattles } & absence & 7,196 & $(70.92)$ & 2,190 & $(30.43)$ & 1,287 & (17.88) & 3,719 & (51.68) \\
\hline & presence & 2,951 & $(29.08)$ & 2,232 & $(75.64)$ & 47 & (1.59) & 672 & (22.77) \\
\hline \multirow{2}{*}{ Long haired } & absence & 10,019 & $(98.74)$ & 4,380 & $(43.72)$ & 1,317 & (13.15) & 4,322 & (43.14) \\
\hline & presence & 128 & $(1.26)$ & 42 & $(32.81)$ & 17 & $(13.28)$ & 69 & $(53.91)$ \\
\hline \multirow{5}{*}{ Horn type } & absence & 73 & $(0.72)$ & 15 & $(20.55)$ & 2 & $(2.74)$ & 56 & (76.71) \\
\hline & Bezoar & 496 & (4.89) & 420 & (84.68) & 18 & (3.63) & 58 & (11.69) \\
\hline & Markhor & 1,022 & $(10.07)$ & 45 & (4.4) & 506 & $(49.51)$ & 471 & (46.09) \\
\hline & Spanish Ibex & 8,529 & $(84.05)$ & 3,917 & (45.93) & 808 & $(9.47)$ & 3,804 & $(44.6)$ \\
\hline & East caucasian & 27 & $(0.27)$ & 25 & $(92.59)$ & 0 & (0) & 2 & $(7.41)$ \\
\hline \multirow{4}{*}{ Ear position } & vertical & 613 & (6.04) & 8 & $(1.31)$ & 600 & $(97.88)$ & 5 & $(0.82)$ \\
\hline & horizontal & 4,054 & $(39.95)$ & 404 & (9.97) & 685 & (16.9) & 2,965 & (73.14) \\
\hline & stalked & 3,754 & (37) & 2,360 & $(62.87)$ & 44 & (1.17) & 1,350 & (35.96) \\
\hline & dropping & 1,726 & (17.01) & 1,650 & $(95.6)$ & 5 & $(0.29)$ & 71 & (4.11) \\
\hline \multirow{2}{*}{ Ear curling } & absence & 8,297 & $(81.77)$ & 3,060 & $(36.88)$ & 1,326 & $(15.98)$ & 3,911 & (47.14) \\
\hline & presence & 1,850 & (18.23) & 1,362 & $(73.62)$ & 8 & $(0.43)$ & 480 & $(25.95)$ \\
\hline \multirow{3}{*}{ Udder } & well-sized & 1,594 & $(15.71)$ & 773 & $(48.49)$ & 555 & $(34.82)$ & 266 & (16.69) \\
\hline & average & 1,073 & (10.57) & 457 & (42.59) & 119 & (11.09) & 497 & (46.32) \\
\hline & small & 7,480 & $(73.72)$ & 3,190 & $(42.67)$ & 660 & (8.82) & 3,630 & $(48.5)$ \\
\hline
\end{tabular}

Chi-squared test showed that incidence of all the analysed traits varied significantly among environmental areas for $\mathrm{p}<0.001$

The between-environmental areas Mahalanobis distance matrix is given in Table 4. All pairwise distances were significant for $\mathrm{p}<0.0001$. The largest distance was found between the Sahelian and Sudan areas (7.50) whilst the goat populations from the Sudan and the Sudan-Sahel areas were poorly differentiated (1.15). The values computed for CAN1 and CAN2 for each individual were plotted by environmental area (Figure 3). The Sudan (Djallonké) individuals were the most homogeneous and clustered together on the left hand of the X-axis; the Sahelians are mainly distributed on the positive values of the X-axis; and the Sudan-Sahelian (Mossi) individuals showed an intermediate distribution but clearly biased toward the Sudan individuals. 
The discriminant analysis carried out gave complementary information on this aspect (Table 5). Most Sahel and Sudan-Sahel individuals were classified into their source population (79.29\% and $82.69 \%)$ whilst the Sudan individuals (93.40\%) were classified as Sudan-Sahel individuals.

Table 4

Mahalanobis distances between the goat populations sampled in each environmental area identified in Burkina Faso (Mahalanobis-Distanzen zwischen den Ziegenpopulationen, die in den einzelnen Habitaten in Burkina Faso untersucht wurden)

\begin{tabular}{lll}
\hline Area & Sahel & Sudan \\
\hline Sudan-Sahel & 4.16 & 1.15 \\
Sudan & 7.50 & \\
\hline
\end{tabular}

Table 5

Percentage of classification into environmental area in Burkina Faso goat using discriminate analysis (Prozentanteil der Habitat-Klassifizierung der Burkina-Faso-Ziege unter Einsatz der Diskriminanzanalyse)

\begin{tabular}{llll}
\hline Area & Sahel & Sudan & Sudan-Sahel \\
\hline Sahel & 79.29 & 0.88 & 19.83 \\
Sudan-Sahel & 15.48 & 1.82 & 82.69 \\
Sudan & 0.60 & 6.00 & 93.40 \\
Total & 41.33 & 1.96 & 56.70 \\
\hline
\end{tabular}

The correspondence analyses carried out on the 12 qualitative traits recorded showed that six of them (colour pattern, melanin type, belt, horns type, ear position and udder development) explained roughly $75 \%$ of the inertia. In consequence, the analysis was re-run using only these 6 traits. Fig. 3 shows the associations among the categories of the different variables considered. The first and second dimensions identified explained, respectively, $41.74 \%$ and $29.35 \%$ of the total variation. On the dimensions identified from the correspondence analysis (not shown) the Sahel area clustered together with dropping and brown melanin type, the Sudan area was closely associated with goats that have vertical ears, wild coat colour pattern absence of wattles and "Spanish Ibex" horns, and the Sudan-Sahel tended to cluster with horizontal ears, black and black and red colour patterns. The values computed for the two identified dimensions for each individual were plotted by environmental area (Figure 4). The scenario identified for each environmental area was similar to that previously reported for the body measures.

The first canonical variable $(\mathrm{CAN} 1)$ was significantly influenced by latitude $(\mathrm{p}<0.0001$; $\mathrm{R}^{2}=0.627$ ) with a regression coefficient of $1.231 \pm 0.01023$, whilst the CAN2 did not vary significantly with latitude $(\mathrm{p}=0.6373)$. The eigenvectors corresponding to the Dimensions 1 and 2 identified via the correspondence analysis were significantly influenced by latitude $(p<0.0001)$ even though the computed coefficients of determination were very low $\left(\mathrm{R}^{2}=0.117\right.$ and $\mathrm{R}^{2}=0.021$, respectively).

\section{Discussion}

Currently, there is an increasing interest on the characterisation of African native genetic resources (NDUMU et al., 2008; OUÉDRAOGO-KONÉ et al., 2006; TRAORE et al., 2008). In the present study an extensive sampling was carried out all over the territory of Burkina Faso to make the first characterisation of its goat population. The average values obtained here for body measures can be compared with others in the literature. The recent paper by DOSSA et al. (2007) on morphological characterisation of Benin goat reported average values for HW, TD, EL and BL of, respectively, 56.57, 26.23, 13.28 and $79.23 \mathrm{~cm}$ for the Northern-Soudanian Benin goat 


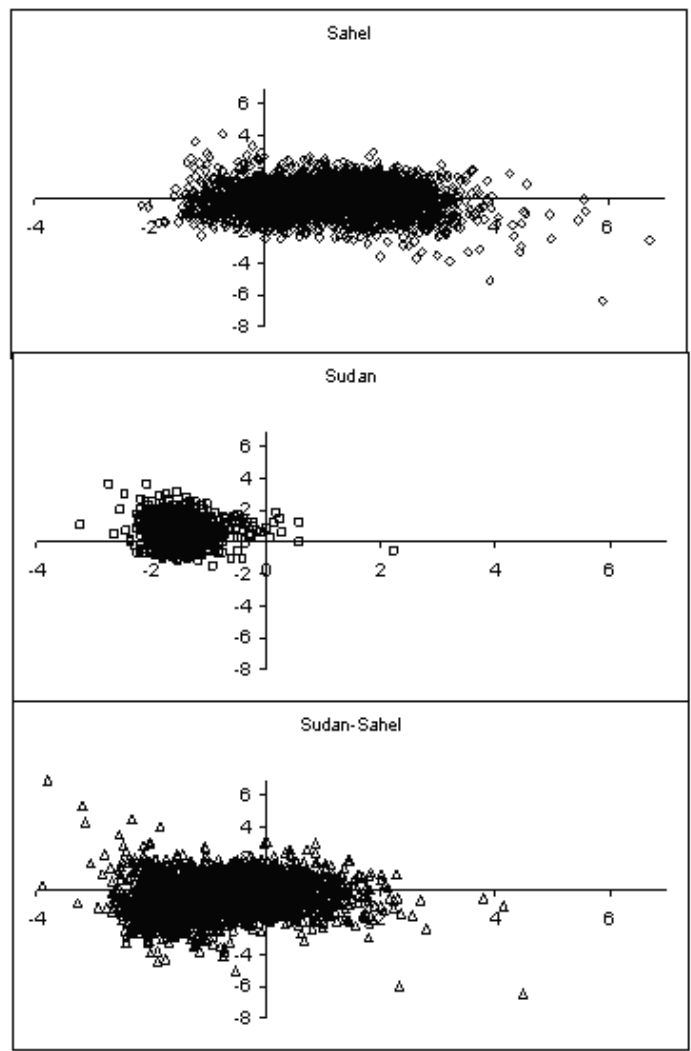

Fig. 3: Bi-dimensional representation of the canonical variables associated to the individuals sampled in each of the environmental areas of Burkina Faso (Zweidimensionale Darstellung der kanonischen Variablen, zugeordnet zu den Individuen, die in den einzelnen Habitaten von Burkina Faso untersucht wurden)

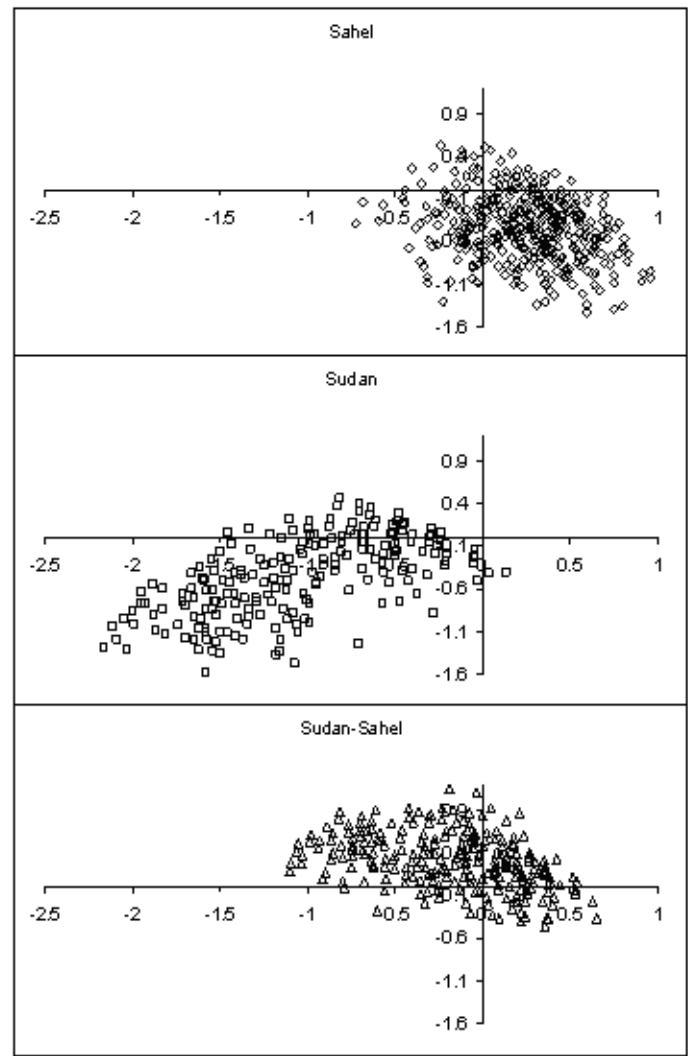

Fig. 4: Bi-dimensional representation of the individuals sampled in each of the environmental areas of Burkina Faso obtained via correspondence analysis (Zweidimensionale Darstellung der in den einzelnen Habitats von Burkina Faso untersuchten Individuen, erhalten durch Korrespondenzanalyse) 
population and 47.44, 25.84, 10.68 and $71.59 \mathrm{~cm}$ for the Southern-Soudanian Benin goat population. These populations would geographically coincide with the Sahelian and Sudan-Sahel Burkina Faso goat populations. The large differences in BL between Burkina Faso and Benin goats can be partially explained by different methodologies used in measurement performance. Moreover, the overall inspection of the body measure values reported by DOSSA et al. (2007) suggest that the Northern-Soudanian Benin goat would be nearer to the Sudan-Sahel (Mossi) Burkina Faso goat (slenderness and auricular indices of 1.16 and 0.51 vs. 1.20 and 0.50) whilst the Sudano-Guinean Benin goat would be more similar to the Sudan population of Burkina Faso (slenderness and auricular indices of 0.72 and 0.39 vs. 1.07 and 0.43 ). The body size of the Sudan (Djallonké) goat of Burkina Faso seems to be higher than other West African Dwarf goat populations. Average values for HW, TD, EL and BL reported by DOSSA et al. (2007) in the coastal goat population of Benin were of, respectively, 41.82, 24.69, 9.45 and $69.68 \mathrm{~cm}$. Morphometrical studies involving Sahelian goat are scant: MOHAMMED and AMIN (1996) reported mean HW in non-pregnant Sahelian does in Nigeria of $60 \pm 5.2 \mathrm{~cm}$; the mean HW of the Red Sokoto goat, which is considered a transition breed between Sahelians and Djallonkés present in Southern Niger, was $58.2 \pm 1.7 \mathrm{~cm}$ (NGERE et al., 1984, cited by DOSSA et al., 2007); BOURZAT et al. (1993) and SEUH et al. (1997) reported mean values for Chadian goat varying from $63 \pm 0.6 \mathrm{~cm}$ to $70 \pm 0.4 \mathrm{~cm}$. These values are, in general, consistent with that of HW reported here for the Sahelian goat.

About qualitative traits, it can be noted that presence of beard and wattles is more frequent $(24.67 \%$ and $29.51 \%$, respectively) in Burkina Faso goat than in other neighbour populations such as that of Benin $(8.1 \%$ and $4.4 \%$, respectively; DOSSA et al. (2007). Both beard and wattles are more frequent in the Sahelian goat than in the Dwarf type individuals (DAGRIS, 2007). In the present study, the Sahelian individuals were $75.64 \%$ and $60.45 \%$ of the animals with, respectively, beard and wattles.

At least at the morphological level, the Sudan-Sahel (Mossi) goat breed of Burkina Faso takes an intermediate position between the Sudan (Djallonkés) and Sahelian goat populations. However, differentiation between Sudan (Djallonkés) and SudanSahel (Mossis) can be more evident at the qualitative level (regarding, for instance, to ear position and presence of wattles and beard) rather than to the body size level: the Mahalanobis distance between these two breeds is very low even though significant (1.15; Table 4) and the Sudan (Djallonké) goat individuals are basically classified as Sudan-Sahelian (Mossi) when the discriminate analysis is carried out on body measures (Table 5). In any case, both canonical and correspondence analysis point out that, even though they are closer to the Sudan individuals (Djallonkés), the Sudan-Sahelian (Mossi) individuals share characteristics from the main goat groups in Burkina Faso and their correct clustering is not straightforward (Figures 3 and 4). The Sudan-Sahel goat body size is, in general, significantly higher than that from Sudan goat individuals, probably because of introgression of Sahelian goat, but also because the size of the goat populations in Western and Central Africa increases with the distance to the Atlantic coast (DOSSA et al., 2007; ZEUH et al., 1997). The Sahelian area of Burkina Faso and the whole Western Africa is mainly inhabited by the ethnical group known as Fulani or Peul, nomadic stockbreeders who are major force of exchange of genes between the nomadic-Sahelian goat (in our case) populations and the extant Djallonké-related goat in the Sahel borders. The increase 
of the duration of the dry seasons in West Africa since the 1980s has favoured the introgression of Sahelian goat southward thus probably increasing the morphological variability within the Sudan-Sahel (Mossi) goat.

The presented results show a significant morphological variation all over the territory of the country mainly due to the existence of two main-well differentiated goat populations (Djallonké and Sahelian). The morphological heterogeneity found depends basically on the environmental conditions in which individuals are gathered even though that, at least with respect the major goat groups studied (Sudan-Djallonké and Sahelian), different genetic origins underlie the observed differences. In any case, continuous intercrossing between Djallonkés and Sahelians are likely to occur in the Sudan-Sahel area of Burkina Faso, thus making possible to assessed a significant continuous variation of morphological traits from South Burkina Faso northwards with latitude. Because the distribution of goat breeds in Burkina Faso basically coincides with the main environmental areas (Sahel, Soudan-Sahel and Sudan), the classification of breeds has some morphological support even though it is very little for Mossis.

\section{Acknowledgements}

This paper was partially funded by grants from Fonds de Solidarité Prioritaire (FSPINERA-CIRDES), the International Atomic Energy Agency, No.BKF/5/006 and MEC-INIA, No.RZ07-00002. The research stay of Amadou Traoré, DVM, in SERIDA-Somió was supported by a grant fellowship from the International Atomic Energy Agency, No.BKF/06023. The authors are indebted to the Directors of Animal Resources Offices of the sampled provinces (Burkina Faso) for introducing them to breeders. In memoriam to Georges-Alfred Ky, who geo-referenced all field data collected.

\section{BOUCHEL, D.:}

\section{References}

Contribution to the study of morpho-biometrical indices and their usefulness for the mapping of goat genetic resources Mémoire de DIRS, Université François Rabelais de Tours (1995) [in French]

BOURZAT, D.; ZAFINDRAJAONA, P.S.; LAUVERGNE, J.J.; ZEUH, V.:

Morpho-biometrical comparison between Northern Cameroon and Chad goat. Rev. Elev. Méd. Vét. Pays Trop. 46 (1993), 667-674 [in French]

CAPOTE, J.; DELGADO, J.V.; FRESNO, M.; CAMACHO, M.E.; MOLINA, A.:

DAGRIS: Morphological variability in the Canary goat population. Small Rumin. Res. 27 (1998), 167-162

Domestic Animal Genetic Resources Information System (DAGRIS). (eds. J.E.O. REGE, O. HANOTTE, Y. MAMO, B. ASRAT and T. DESSIE). International Livestock Research Institute, Addis Ababa, Ethiopia (2007). http://dagris.ilri.cgiar.org

DOSSA, L.H.; WOLLNY, C.; GAULY, M.:

Spatial variation in goat populations from Benin as revealed by multivariate analysis of morphological traits. Small Rum. Res. 73 (2007), 150-159

DELGADO, J.V.; BARBA, C.; CAMACHO, M.E.; SERENO, F.T.P.S.; MARTÍNEZ, A.; VEGA-PLA, J.L.: Livestock characterisation in Spain. AGRI 29 (2001), 7-18 [in Spanish]

DUCHEV, Z.; GROENEVELD, E.:

Improving the monitoring of animal genetic resources on National and International level Arch. Tierz.. 49 (2006), 532-544

DUCHEV, Z.; DISTL, O.; GROENEVELD, E.:

Early warning system for loss of diversity in European livestock breeds. Arch. Tierz. 49 (2006), 521-531 
HERRERA, M.; RODERO, E.; GUTIERREZ, M.J.; PENA, F.; RODERO, J.M.: Application of multifactorial discriminant analysis in the morphostructural differentiation of Andalusian caprine breeds. Small Rumin. Res. 22 (1996), 39-47

JORDANA, J.; RIBO, O.; PELEGRIN, M.:

Analysis of genetic relationships from morphological characters in Spanish goat breeds. Small Rumin. Res. 12 (1993), 301-314

KESSLER, J.J.; GEERLING, C.:

Environmental profile of Burkina Faso. U. Agronomique, Départ. Aménag. Nature, Wagenimgen, Pays-Bas (1994) [in French]

LANARI, M.R.; TADDEO, H.; DOMINGO, E.; PÉREZ CENTENO, M.; GALLO, L.:

Phenotypic differentiation of exterior traits in local Criollo Goat Population in Patagonia (Argentina). Arch. Tierz. 46 (2003), 347-356

MASON, I.L.:

Classification and distribution of goats breeds. In: MAIJALA, K. (Ed.), Genetic Resources of Pig, Sheep and Goat (1991), 405-411

MOHAMMED, D.; AMIN, J.D.:

Estimating body weight from morphometric measurements of Sahel (Borno White) goats. Small Rumin. Res. 24 (1997), 1-5

NDUMU, D.B.; BAUMUNG, R.; WURZINGER, M.; DRUCKER, A.G.; OKEYO, A.M.; SEMAMBO, D.; SÖLKNER, J.:

Performance and fitness traits versus phenotypic appearance in the African Ankole Longhorn cattle: A novel approach to identify selection criteria for indigenous breeds. Livest. Sci. 113 (2008), 234-242

OUADBA, J.M.

Development of national monograph on the biological diversity of Burkina Faso: Data gathering, ecological considerations. Minist. Envir. et de 1'Eau, Ouagadougou (1997) [in French]

OUEDRAOGO-KONE, S.; KABORE-ZOUNGRANA, C.Y.; LEDIN, I.:

Behaviour of goats, sheep and cattle on natural pasture in the sub-humid zone of West Africa. Livest. Sci. 105 (2006), 244-252

SANFO, R.; NIANOGO, A.J.; TAMBOURA, H.H.:

Morpho-biometrical profile, census evolution and production indices in the Sahel goat of Burkina Faso. Sci. Tech. 24 (2000), 68-76 [in French]

SAS/ STAT:

User's Guide, Release 8.2. SAS Institute Inc. (1999)

SIMON, D.L.:

European approaches to conservation of farm animal genetic resources. AGRI 25 (1999), 79-99

TRAORE, A.; TAMBOURA, H.H.; KABORE, A.; YAMEOGO, N.; BAYALA, B.; ZARÉ, I.:

Morphological characterisation of the Mossi sheep and goat breeds of Burkina Faso. AGRI 39 (2006), 39-50 [in French]

TRAORE, A.; TAMBOURA, H.H.; KABORE, A.; ROYO, L.J.; FERNANDEZ, I.; ÁLVAREZ, I.; SANGARE, M.;

BOUCHEL, D.; POIVEYE, J.P.; FRANCOIS, D.; TOGUYENI, A.; SAWADOGO, L.; GOYACHE, F.: Multivariate characterisation of morphological traits in Burkina Faso sheep. Small Rum. Res. (2008) [in press]

TAMBOURA, H.; SAWADOGO, L.; WEREME, A.:

Temporal and endocrine characteristics of the oestral cycle and puberty in the local Mossi goat breed of Burkina Faso. Biotech. Agron. Soc. Environ. 2 (1998), 85-91 [in French]

WILSON, T.

Small ruminant production and the small ruminant genetic resource in Tropical Africa. FAO Animal Production and Health Paper 88, Rome (1999)

ZAITOUN, I.S.; TABBAA, M.J.; BDOUR, S.:

Differentiation of native goat breeds of Jordan on the basis of morphostructural characteristics. Small Rumin. Res. 56 (2005), 173-182

ZEUH, V.; LAUVERGNE, J.J.; BOURZAT, D.; MINVIELLE, F.:

Cartography of the goat genetique resources of Southwestern Chad. I. Height at withers, thorax depth and slenderness index. Rev. Elev. Méd. Vét. Pays Trop. 50 (1997), 250-260 [in French] 
Authors:

AMADOU TRAORÉ

HAMIDOU H. TAMBOURA

ADAMA KABORÉ

Institut de 1'Environnement et de Recherches Agricoles (INERA)

Unité d'étude et de Recherches en Biologie et Santé Animale

04 BP 8645 Ouagadougou 04

Burkina Faso

MAMADOU SANGARE

Centre International de Recherche-Développement sur l'Elevage

en Zones Sub-Humides (CIRDES)

01 BP 454 Bobo-Dioulasso

Burkina Faso

DIDIER BOUCHEL

Institut Sénégalais de Recherches Agricoles (ISRA)

BP 24187 Dakar Ouakam

Sénégal

JEAN PAUL POIVEY

Centre International de Recherches Agronomiques pour le Développement (CIRAD)

Campus de Baillarguet

F 34000 Montpellier

France

DOMINIQUE FRANCOIS

Institut National de Recherche Agronomique (INRA)

Station d'Amélioration Génétique des Animaux (SAGA)

INRA-SAGA Toulouse, BP 25627

F-31326 Castanet Tolosan Cedex

France

LAYA SAWADOGO

Laboratoire de Physiologie animale

Unité de Formation et de Recherche en Sciences de la Vie et de la Terre

(UFR/SVT)

Université de Ouagadougou

03 BP 7021 Ouagadougou 03

Burkina Faso

IVÁN FERNÁNDEZ

ISABEL ÁLVAREZ

LUIS J. ROYO

FÉLIX GOYACHE*

Área de Genética y Reproducción Animal

SERIDA-Somió

C/Camino de los Claveles 604

E-33203 Gijón (Asturias)

Spain

*Corresponding author

email: fgoyache@serida.org 